\title{
Standardization of Grafting in Bittergourd (Momordica charantia L.)
}

\author{
K.P. Aiswarya V. Dev' ${ }^{1}$ M. Rafeekher ${ }^{2}$, S. Sarada ${ }^{3}$
}

10.18805/IJARe.A-5864

\begin{abstract}
Background: Commercial cultivation of bitter gourd is affected by biotic stresses like mosaic disease, fusarium wilt and root-knot nematode as well as abiotic stress like drought. Grafting with resistant rootstocks can be a tool to control these problems. In vegetable production, grafting is exploited commercially in many parts of the world. The cultivated area of grafted solanaceae and cucubitaceae plants has increased tremendously in recent years because of the advantages of grafted plants. Commercial use of vegetable grafting is a relatively recent innovation in India and scientific information on grafting in bittergourd is meager. In this context, identification of suitable rootstocks and standardization of grafting techniques that do not have adverse effect on yield and fruit quality not only lay foundation for further evaluation on tolerance to different biotic and abiotic stresses but also enhance the area and production of bitter gourd especially in sustainable production systems.

Methods: Grafting in bitter gourd was carried out with three grafting methods such as hole insertion grafting, one cotyledon grafting and cleft grafting using growth regulators viz., alar and CCC to control height of rootstocks in order to identify suitable method, growth regulator and its concentration. The grafting experiment was done independently to four cucurbitaceous rootstocks viz., sponge gourd, pumpkin, bottle gourd and bitter gourd using bittergourd var. Preethi as scion. Height and diameter of the rootstocks before grafting were recorded and then the growth regulators alar and CCC each at $10 \mathrm{mgL}^{-1}$ and $50 \mathrm{mgL}^{-1}$ along with distilled water as control were sprayed on rootstocks in order to prevent the lodging of the root stocks and then grafted using different methods. Days taken for graft union and percentage success were also evaluated after grafting.

Result: Our study of grafting bitter gourd scion into four cucurbitaceous rootstocks utilizing three methods and two growth regulators at two different concentration along with control exhibited significant difference in graft success among the methods as well as concentration of growth regulator in all four experiments. This work can be further utilized for imparting resistance against abiotic and biotic stresses in bitter gourd by selecting suitable rootstocks.

Key words: Bitter gourd, Cleft grafting, Cucurbitaceous rootstocks, Growth regulators, Hole insertion grafting, One cotyledon grafting, Vegetable grafting.
\end{abstract}

\section{INTRODUCTION}

Bitter gourd (Momordica charantia L.) is one of the most important cucurbitaceous vegetables originated in India and widely grown throughout Asia, East Africa and South America. It is considered as an esteemed vegetable because of its high nutritive value particularly iron and ascorbic acid. It is a relatively cheap source of proteins, minerals, fats and vitamins. Immature fruit is a chief source of vitamin $C$, vitamin A, iron and phosphorus (Behera, 2005). The fruit contains 2 $\mathrm{mg}$ of iron, $88 \mathrm{mg}$ of vitamin $\mathrm{C}, 2.1 \mathrm{~g}$ of protein, $20 \mathrm{mg}$ of calcium, $55 \mathrm{mg}$ of phosphorus and $210 \mathrm{IU}$ of vitamin A in $100 \mathrm{~g}$ of edible portion. Tender fruits and vine tips are highly nutritious. In Asia and some African countries, bitter gourd is consumed as a vegetable and also used as folk medicine for controlling Type 2 diabetes, yet designated as plant insulin. Bitter gourd is cultivated in vast areas due to high demand in market (Tamilselvi, 2013).

The crop is cultivated over an area of 97,000 ha in India with an annual production of 1,137,000 tonnes and the productivity of $11.72 \mathrm{t} \mathrm{ha}^{-1}$. Karnataka, Maharashtra, Tamil Nadu and Kerala are the major bitter gourd growing states in India. (Anonymous, 2016) Hence this crop requires attention from breeders and production system specialists.
${ }^{1}$ Department of Vegetable Science, College of Agriculture, Kerala Agricultural University, Vellayani, Thiruvananthapuram-695 522, Kerala, India.

${ }^{2}$ Department of Fruit Science, College of Agriculture, Vellayani, Kerala Agricultural University, Thiruvananthapuram-695 522, Kerala, India. ${ }^{3}$ Department of Vegetable Science, College of Agriculture, Vellayani, Kerala Agricultural University, Thiruvananthapuram-695 522, Kerala, India.

Corresponding Author: K.P. Aiswarya V. Dev, Department of Vegetable Science, College of Agriculture, Vellayani, Kerala Agricultural University, Thiruvananthapuram-695 522, Kerala, India. Email: aiswaryavdev2825@gmail.com

How to cite this article: Aiswarya V. Dev, K.P., Rafeekher, Sarada, M.S. (2022). Standardization of Grafting in Bittergourd (Momordica charantia L.). Indian Journal of Agricultural Research. DOI: 10.18805/IJARe.A-5864.

Submitted: $26-06-2021 \quad$ Accepted: 11-11-2021 Online: 14-01-2022

Commercial cultivation bitter gourd is affected by biotic stresses like mosaic disease, fusarium wilt and root-knot nematode as well as abiotic stress like drought (Lin et al. 1998). Davis et al. (2008) reported that environmental stresses represent the most restraining conditions for 
horticultural productivity. These conditions include too cold, wet and dry weather.

Grafting is an old asexual plant propagation method that utilizes two plant segments, the'scion'(shoot piece) and 'rootstock'(root piece) combine to form a new plant. (Goldschmidt, 2014). The cultivated area of grafted solanaceous and cucubitaceous vegetables has increased enormously due to varying grafting motives (Lee et al, 2010) and it is currently regarded as a possible quick choice against the time consuming breeding methodology focused at increasing tolerance against environmental-stress in vegetables (Flores et al, 2010). Pradeep et al. (2017) stated grafting as an efficient method with ambient potential to boost the productivity of modern vegetable cultivation with increased resistance against stress conditions.

The root system conferred by the rootstock and the vigour of the scion help the plant in its growth and establisment even in the presence of pathogen (Cohen et al, 2000). Pumpkin, fig leaf gourd, luffa (Luffa spp.), bottle gourd and interspecific pumpkin hybrids (C. maxima x C. moschata) are commonly used rootstocks for bitter gourd (Lin 2004; Sun et al, 2009).

Bitter gourd grafted on luffa through wedge grafting had been a trend in China and Taiwan against Fusarium wilt (Chung and Chin 1996) and also showed remarkable increase in yield (Palada and Chang 2003). Hang et al. (2005) suggested that when scion and rootstock possess hollow hypocotyls, the hole insertion and one cotyledon grafting methods are mostly preferred in cucurbits. They also found that cleft grafting, one cotyledon grafting and hole insertion grafting methods reduced the chance of adventitious roots of scion catching soil borne diseases due to the space between scion and the ground. Sun et al. (2009) suggested the tongue approach, hole insertion and cleft grafting as the most commonly used grafting methods in bitter gourd.

Cycocel is an excellent growth retardant widely used for dwarfing plants (Bora and Sarma, 2004) and it the reduced internodal length by blocking biosynthesis of GA (Davie, 1995). CCC (1000 $\left.\mathrm{mgL}^{-1}\right)$ found to be successful in reducing growth upto 14.72 per cent in water melon compared to the control (Shinde et al, 1994). Yadav and Sreenath (1975) observed that alar applied to cow pea plant as foliar spray significantly lowered plant height, but increased the leaf number and yield.

In this context, standardization of grafting techniques that do not have adverse effect on yield and fruit quality using different rootstocks becomes necessary as it not only lay foundation for further evaluation on tolerance to different biotic and abiotic stresses but also enhance the area and production of bitter gourd especially in sustainable production systems.

\section{MATERIALS AND METHODS}

The study was conducted in the Department of Vegetable Science, College of Agriculture, Vellayani, Kerala Agricultural
University, India during 2018-2019. Bittergourd (Momordica charantia L) variety, Preethi was used as the scion. Sponge gourd (Luffa cylindrica) variety Gujarat Junagadh Sponge Gourd-2(GJSG-2), pumpkin (Cucurbita moschata) variety Ambili, bottle gourd (Lagenaria siceraria) variety Arka Bahar and bittergourd (Momordica charantia $\mathrm{L}$ ) variety Preethi were selected as rootstocks and used for grafting. Two growth regulators viz., alar and cycocel each at $10 \mathrm{mgL}^{-1}$ and $50 \mathrm{mgL}^{-}$ ${ }^{1}$ were sprayed at 2-4 leaf stage to control height of rootstocks. The requirements of operations were razor blade for cutting stock and scion, grafting clips for securing graft union and mist chamber for keeping grafted plants. The mist chamber used consisted of two layers viz., inside made up of high density polyethylene (HDPE) and outside made up of shade net. The relative humidity between 85 and 95 per cent and the temperature between 25 and $30^{\circ} \mathrm{C}$ were maintained by bottom cooling with water sprinkled twice a day. The experiment was conducted in completely randomized design (CRD) with three replications. A total of twenty five grafts were maintained per replication of each treatment. The methods of grafting employed were hole insertion grafting, one cotyledon grafting and cleft grafting. Grafting was performed in 10-14 days old seedlings.

Days taken to attain graftable size, height of rootstock at grafting $(\mathrm{cm})$, diameter of rootstock at grafting $(\mathrm{mm})$, days taken for graft union, percentage success (\%) were recorded. Grafting success was recorded at 9 days after grafting (DAG). Complete break down at the graft area and differences in stem diameter between scion and rootstock followed by scion wilting was considered as unsuccessful grafts.

The percentage of success was recorded by the formula:

$$
\begin{aligned}
& \text { Per cent graft success }= \\
& \qquad \frac{\text { Number of successful grafts }}{\text { Total number of plants grafted }} \times 100
\end{aligned}
$$

Statistical analysis of the above mentioned observations was done in WASP 2.0 software and treatments were compared.

\section{RESULTS AND DISCUSSION \\ Days taken to attain graftable size}

Among the rootstocks, pumpkin attained graftable size earlier (7 days), since it germinated faster compared to other rootstocks followed by bottle gourd (Table 1). Even though sponge gourd germinated faster, it did not reach graftable size earlier like pumpkin because of its thinner stem diameter. Bitter gourd took more days to attain graftable size (14 days) due to its late germination. The result is in conformity with Akhila and George (2017), who stated that standards for the scions and rootstocks to reach graftable size were based on width of scion and rootstock and their aptness for grafting method and pumpkin and bottle gourd took the least number of days to attain graftable size (Akhila and George, 2017). 


\section{Height of rootstock at grafting}

Spraying of alar significantly reduced the height of rootstock in sponge gourd, pumpkin, bottle gourd and bitter gourd. Application of alar @ $10 \mathrm{mgL}^{-1}$ reduced height in sponge gourd and bitter gourd rootstocks and alar@ $050 \mathrm{mgL}^{-1}$ significantly reduced the height in bottle gourd rootstock. In pumpkin, spraying of alar in both concentration showed reduction in height (Table 2). Maiko and Musat (1977) stated that B-9 or alar stops biosynthesis of GA as well as its activity. This might be the cause for shorter plant heights. Cycocel at its higher and lower concentration reduced the height of bitter gourd rootstocks. The retardation in plant

Table 1: Days taken by rootstocks attain graftable size.

\begin{tabular}{lc}
\hline Rootstocks & Days taken to attain graftable size \\
\hline Sponge gourd & 10.33 \\
Pumpkin & 7.00 \\
Bottle gourd & 8.67 \\
Bitter gourd /scion & 14.00 \\
SE $(m) \pm$ & 0.373 \\
CD $(0.05)$ & 1.234 \\
\hline
\end{tabular}

height caused by cycocel might be due to shortening of internodes by decreasing cell division and cell numbers (Child, 1984).

\section{Diameter of rootstock at grafting}

Application of alar in both concentrations was effective in improving diameter of sponge gourd rootstock. Spraying in its lower concentration improved diameter of bitter gourd rootstock and spraying in its higher concentration improved the diameter of bottle gourd rootstock (Table 2). Brittain (1967) reported similar findings with alar treated peanut plants, wherein pith parenchyma cells showed higher diameter than cells of untreated plants, thus causing the stem diameter to be larger in treated plants.

Application of cycocel in both concentrations was effective in improving diameter of pumpkin rootstock. Spraying in its lower concentration improved diameter of bitter gourd rootstock and spraying in its higher concentration improved the diameter of bottle gourd rootstock. The result was in agreement with Grzyb (1982), who stated that CCC showed a very crucial effect on the increasing diameter of shoot in Brompton plum.

Table 2: Effect of growth regulator on height and diameter of rootstock at grafting when grafted on different rootstocks.

\begin{tabular}{|c|c|c|c|}
\hline Rootstocks & Treatments & $\begin{array}{l}\text { Height of rootstock } \\
\text { at grafting }(\mathrm{cm})\end{array}$ & $\begin{array}{c}\text { Diameter of rootstock } \\
\text { at grafting }(\mathrm{mm})\end{array}$ \\
\hline \multirow[t]{7}{*}{ Sponge gourd } & $\mathrm{R}_{0}$ - Distilled water (control) & 9.02 & 2.67 \\
\hline & $\mathrm{R}_{1}-$ Alar @ $10 \mathrm{mgL}^{-1}$ & 7.50 & 2.97 \\
\hline & $\mathrm{R}_{2}-$ Alar @ $50 \mathrm{mgL}^{-1}$ & 8.86 & 3.01 \\
\hline & $\mathrm{R}_{3}$ - Cycocel @ $10 \mathrm{mgL}^{-1}$ & 8.46 & 2.75 \\
\hline & $\mathrm{R}_{4}$ - Cycocel @ $50 \mathrm{mgL}^{-1}$ & 8.69 & 2.75 \\
\hline & $\mathrm{SE} \pm(\mathrm{m})$ & 0.174 & 0.084 \\
\hline & CD (0.05) & 0.506 & 0.244 \\
\hline \multirow[t]{7}{*}{ Pumpkin } & $\mathrm{R}_{0}-$ Distilled water (control) & 15.41 & 3.67 \\
\hline & $\mathrm{R}_{1}$ - Alar @ $10 \mathrm{mgL}^{-1}$ & 12.30 & 4.15 \\
\hline & $\mathrm{R}_{2}-$ Alar @ $50 \mathrm{mgL}^{-1}$ & 12.85 & 3.84 \\
\hline & $\mathrm{R}_{3}$ - Cycocel @ $10 \mathrm{mgL}^{-1}$ & 13.59 & 4.99 \\
\hline & $\mathrm{R}_{4}-$ Cycocel @ $50 \mathrm{mgL}^{-1}$ & 13.63 & 4.77 \\
\hline & $\mathrm{SE} \pm(\mathrm{m})$ & 0.396 & 0.125 \\
\hline & CD (0.05) & 1.148 & 0.313 \\
\hline \multirow[t]{7}{*}{ Bottle gourd } & $\mathrm{R}_{0}$ - Distilled water (control) & 13.53 & 3.67 \\
\hline & $\mathrm{R}_{1}$ - Alar @ $10 \mathrm{mgL}^{-1}$ & 14.27 & 4.65 \\
\hline & $\mathrm{R}_{2}-$ Alar @ $50 \mathrm{mgL}^{-1}$ & 12.61 & 4.21 \\
\hline & $\mathrm{R}_{3}$ - Cycocel @10 mgL-1 & 13.59 & 4.16 \\
\hline & $\mathrm{R}_{4}$ - Cycocel @ $50 \mathrm{mgL}^{-1}$ & 14.58 & 4.39 \\
\hline & $\mathrm{SE} \pm(\mathrm{m})$ & 0.298 & 0.120 \\
\hline & CD (0.05) & 0.866 & 0.347 \\
\hline \multirow[t]{7}{*}{ Bitter gourd } & $\mathrm{R}_{0}$ - Distilled water (control) & 11.57 & 3.52 \\
\hline & $\mathrm{R}_{1}-$ Alar @ $10 \mathrm{mgL}^{-1}$ & 10.46 & 3.50 \\
\hline & $\mathrm{R}_{2}$ - Alar @ $50 \mathrm{mgL}^{-1}$ & 11.45 & 3.77 \\
\hline & $\mathrm{R}_{3}$ - Cycocel @ $10 \mathrm{mgL}^{-1}$ & 10.76 & 3.84 \\
\hline & $\mathrm{R}_{4}-$ Cycocel @ $50 \mathrm{mgL}^{-1}$ & 10.87 & 3.88 \\
\hline & $\mathrm{SE} \pm(\mathrm{m})$ & 0.219 & 0.096 \\
\hline & CD $(0.05)$ & 0.635 & 0.146 \\
\hline
\end{tabular}


Table 3: Effect of grafting method on days taken for graft union and percentage success in different rootstock.

\begin{tabular}{|c|c|c|c|}
\hline Rootstocks & Treatments & Days taken for graft union & Percentage success (\%) \\
\hline \multirow[t]{5}{*}{ Sponge gourd } & $\mathrm{G}_{1}-$ Hole insertion grafting & 4.11 & 77.07 \\
\hline & $\mathrm{G}_{2}$ - One cotyledon grafting & 5.67 & 54.93 \\
\hline & $\mathrm{G}_{3}-$ Cleft grafting & 5.09 & 10.93 \\
\hline & $\mathrm{SE} \pm(\mathrm{m})$ & 0.126 & 1.033 \\
\hline & CD (0.05) & 0.367 & 2.997 \\
\hline \multirow[t]{5}{*}{ Pumpkin } & $\mathrm{G}_{1}$ - Hole insertion grafting & 3.51 & 59.47 \\
\hline & $\mathrm{G}_{2}$ - One cotyledon grafting & 4.47 & 68.60 \\
\hline & $\mathrm{G}_{3}$ - Cleft grafting & 7.07 & 11.20 \\
\hline & $\mathrm{SE} \pm(\mathrm{m})$ & 0.120 & 2.720 \\
\hline & CD (0.05) & 0.350 & 7.893 \\
\hline \multirow[t]{5}{*}{ Bottle Gourd } & $\mathrm{G}_{1}$ - Hole insertion grafting & 3.69 & 74.40 \\
\hline & $\mathrm{G}_{2}$ - One cotyledon grafting & 5.29 & 86.40 \\
\hline & $\mathrm{G}_{3}-$ Cleft grafting & 6.27 & 17.33 \\
\hline & $\mathrm{SE} \pm(\mathrm{m})$ & 0.124 & 1.873 \\
\hline & CD (0.05) & 0.359 & 5.436 \\
\hline \multirow[t]{5}{*}{ Bitter gourd } & $\mathrm{G}_{1}$ - Hole insertion grafting & 3.57 & 68.13 \\
\hline & $\mathrm{G}_{2}$ - One cotyledon grafting & 4.85 & 63.87 \\
\hline & $\mathrm{G}_{3}-$ Cleft grafting & 7.58 & 23.73 \\
\hline & $\mathrm{SE} \pm(\mathrm{m})$ & 0.099 & 0.662 \\
\hline & CD (0.05) & 0.287 & 1.922 \\
\hline
\end{tabular}

Table 4: Effect of growth regulator on days taken for graft union and percentage success in different rootstock.

\begin{tabular}{|c|c|c|c|}
\hline Rootstocks & Treatments & Days taken for graft union & Percentage success (\%) \\
\hline \multirow[t]{7}{*}{ Sponge gourd } & $\mathrm{R}_{0}-$ Distilled water (control) & 4.96 & 43.56 \\
\hline & $\mathrm{R}_{1}-$ Alar @ $10 \mathrm{mgL}^{-1}$ & 4.74 & 45.33 \\
\hline & $\mathrm{R}_{2}-$ Alar @ $50 \mathrm{mgL}^{-1}$ & 5.00 & 45.78 \\
\hline & $\mathrm{R}_{3}-$ Cycocel @ $10 \mathrm{mgL}^{-1}$ & 5.00 & 47.11 \\
\hline & $\mathrm{R}_{4}-$ Cycocel @ $50 \mathrm{mgL}^{-1}$ & 5.07 & 56.44 \\
\hline & $\mathrm{SE} \pm(\mathrm{m})$ & 0.163 & 1.333 \\
\hline & CD (0.05) & NS & 3.870 \\
\hline \multirow[t]{7}{*}{ Pumpkin } & $\mathrm{R}_{0}$ - Distilled water (control) & 5.22 & 41.56 \\
\hline & $\mathrm{R}_{1}-$ Alar @ $10 \mathrm{mgL}^{-1}$ & 4.81 & 54.11 \\
\hline & $\mathrm{R}_{2}-$ Alar @ $50 \mathrm{mgL}^{-1}$ & 5.00 & 49.33 \\
\hline & $\mathrm{R}_{3}-$ Cycocel @ $10 \mathrm{mgL}^{-1}$ & 4.89 & 47.11 \\
\hline & $\mathrm{R}_{4}-$ Cycocel @ $50 \mathrm{mgL}^{-1}$ & 5.15 & 40.00 \\
\hline & $\mathrm{SE} \pm(\mathrm{m})$ & 0.156 & 3.511 \\
\hline & CD (0.05) & NS & 10.190 \\
\hline \multirow[t]{7}{*}{ Bottle Gourd } & $\mathrm{R}_{0}$ - Distilled water (control) & 4.93 & 63.11 \\
\hline & $\mathrm{R}_{1}-$ Alar @ $10 \mathrm{mgL}^{-1}$ & 4.96 & 59.11 \\
\hline & $\mathrm{R}_{2}-$ Alar @ $50 \mathrm{mgL}^{-1}$ & 5.19 & 54.67 \\
\hline & $\mathrm{R}_{3}-$ Cycocel @ $10 \mathrm{mgL}^{-1}$ & 5.04 & 61.78 \\
\hline & $\mathrm{R}_{4}-$ Cycocel @ $50 \mathrm{mgL}^{-1}$ & 5.30 & 58.22 \\
\hline & $\mathrm{SE} \pm(\mathrm{m})$ & 0.160 & 2.418 \\
\hline & CD (0.05) & NS & 7.003 \\
\hline \multirow[t]{7}{*}{ Bitter gourd } & $\mathrm{R}_{0}-$ Distilled water (control) & 5.24 & 52.44 \\
\hline & $\mathrm{R}_{1}-$ Alar @ $10 \mathrm{mgL}^{-1}$ & 5.43 & 41.33 \\
\hline & $\mathrm{R}_{2}-$ Alar @ $50 \mathrm{mgL}^{-1}$ & 5.22 & 53.33 \\
\hline & $\mathrm{R}_{3}-$ Cycocel @10mgL-1 & 5.21 & 48.00 \\
\hline & $\mathrm{R}_{4}-$ Cycocel @ $50 \mathrm{mgL}^{-1}$ & 5.56 & 64.44 \\
\hline & $\mathrm{SE} \pm(\mathrm{m})$ & 0.128 & 0.855 \\
\hline & CD (0.05) & NS & 2.481 \\
\hline
\end{tabular}




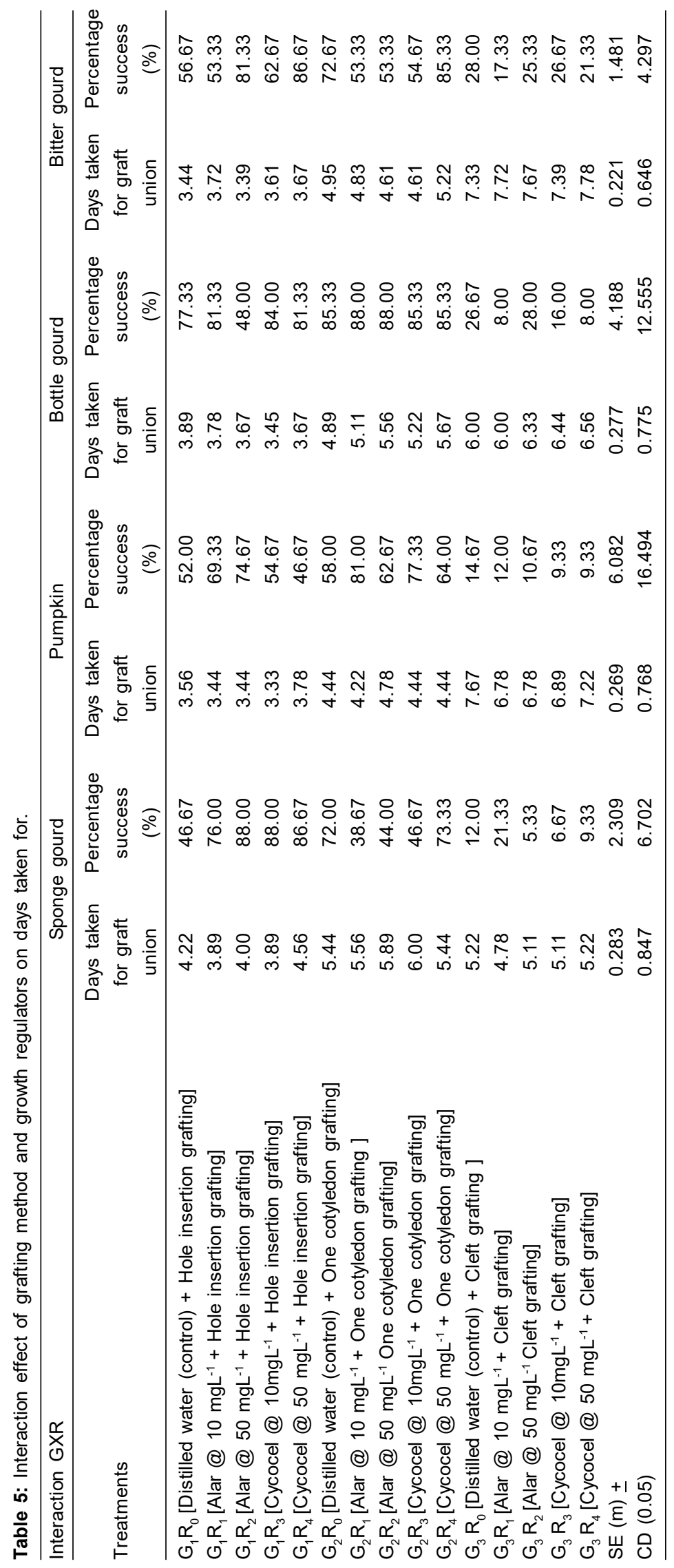




\section{Days taken for graft union}

Among the three grafting methods, faster graft union took place in hole insertion grafting in all the rootstocks (Table 3). This might be due to the deliberate avoidance of grafting clip in the hole insertion method. When clips were used, squeezing of tissues took place resulted in slower graft union. This is in conformity with Punithaveni et al. (2014) who stated that 'Green long' cucumber grafted on bottle gourd took minimum number of days (6.75) for graft union.

In all the rootstocks, growth regulator did not influence the days taken for graft union (Table 4). However the combination showed significant variation (Table 5 ). The combination of growth regulators with hole insertion grafting method took less days for graft union.

\section{Percentage success}

The success of grafting depends on various factors such as size of scion and rootstock, cultural condition, method of grafting, tissue and structure differences, biochemical and physiological characteristics, growth stage of rootstock and scion, phytohormone and environment (Davis et al. 2008).

Among the methods, hole insertion recorded the highest success percentage in sponge gourd as well as bitter gourd rootstock, where as one cotyledon grafting was best in terms of success percentage in pumpkin as well as bottle gourd rootstocks (Table 3 ). This is in agreement with Hassell et al. (2008) who claimed that when rootstock and scion possess hollow hypocotyls, the hole insertion grafting and one-cotyledon grafting methods are more favored. Guan and Zhao (2015) reported that the plants grafted with the onecotyledon method in musk melon recorded the highest survival rate $(100 \%)$, indicating that this method may have a low requirement for bigger sizes of rootstock and scion and also stated that the decline of grafted plants using no cotyledon method may be due to the inhibited root growth resulting from the removal of both cotyledons from the rootstock.

From Table 4, it is evident that spraying cycocel @ 50 $\mathrm{mgL}^{-1}$ was effective in sponge gourd and bitter gourd rootstocks while, alar @ $10 \mathrm{mgL}^{-1}$ was effective for pumpkin rootstock. Spraying of growth regulator had no role in success percentage in bottle gourd rootstock.

\section{CONCLUSION}

From the above results, it can be concluded that higher success rate can be obtained when grafts are produced by cycocel @ $50 \mathrm{mgL}^{-1}$ along with hole insertion grafting in sponge gourd, alar @ $10 \mathrm{mgL}^{-1}$ along with one cotyledon grafting in pumpkin, distilled water (control) along with one cotyledon grafting in bottle gourd and cycocel @ $50 \mathrm{mgL}^{-1}$ along with hole insertion grafting in bitter gourd. These successful treatments from each rootstocks were further evaluated for growth, yield and quality. The grafts which shows best establishment percentage in field can be utilized to incorporate resistance against abiotic and biotic stresses.

\section{REFERENCES}

Akhila, A.N. and George, S.T. (2017). Standardisation of grafting in bitter gourd (Momordica charantia L.). Journal of Tropical Agriculture. 55: 167-174.

Anonymous, (2016). National Horticulture Board, Government of India. Behera, T.K. (2005). Heterosis in bitter gourd. Journal of New Seeds. 6: 217-221.

Bora, R.K. and Sarma, C.M. (2004). Effect of GA3 and CCC on growth, yield and protein content of soybean (cv. Ankur). Environmental Biology and Conservation. 9: 59-65.

Brittain, J.A. (1967). Response of Arachis hypogaea L. to succinic acid 2, 2-dimethyl hydrazide. Ph.D. thesis, Virginia Polytechnic Institute, Blacksburg, Va. p.81.

Child, R.D. (1984). Effects of growth retardants and ethephon on growth and yield formation in oilseed rape. Aspects of Applied Biology. 6: 127-136.

Chung, T.L. and Chin, L. (1996). Photosynthetic responses of grafted bitter melon seedlings to flood stress. Environmental and Experimental Botany. 36: 167-172.

Cohen, R., Pivonia, S., Burger, Y., Edelstein, M., Gamliel, A. and Katan, J. (2000). Toward integrated management of Monosporascus wilt of melons in Israel. Plant Disease. 84: 496-505.

Davies, P.J. (1995). Plant Hormones, Physiology, Biochemistry and Molecular Biology. Kluwer Academic Publishers, Dordrech. pp. 246.

Davis, A.R., Veazie, P.P., Sakata, Y., Galarza, S.L., Maroto, J.V., Lee, S.G., Huh, Y.C., Sun, Z., Miguel, A., King, S.R., Cohen, R. and Lee, J.M. (2008). Cucurbit grafting. Critical Reviews in Plant Sciences. 27: 50-74.

Flores, F.B., Sanchez-Bel, P., Estan, M.T., Martinez-Rodriguez, M.M., Moyano, E., Morales, B., Campos, J.F., Gracia-Abellan, J.O., Egea, M.I., Fernandeze-Garcia, N., Romojaro, F. and Bolarin, M.C. (2010). The effectiveness of grafting to improve tomato fruit quality. Scientia Horticulturae. 125: 211-217.

Goldschmidt, E.E. (2014) Plant grafting: New mechanisms, evolutionary implications. Frontiers in Plant Science. 5: 727.

Grzyb, Z.S. (1982). Growth and rooting of Brompton plum, F 12/1 cherry and M 26 apple clonal rootstocks. Pt. 2 Effect of Ethrel, CCC and Alar on the pattern of shoot growth and the initiation of adventitious roots. Fruit Science Reports. 9: 1-11.

Guan, W. and Zhao, X. (2015). Effects of grafting methods and root excision on growth characteristics of grafted muskmelon plants. Horticultural Technology. 25: 706-713.

Hang, S.D., Zhao, Y.P., Wang, G.Y. and Song, G.Y. (2005). Vegetable Grafting. China Agriculture Press, Beijng, China. 289.

Hassell, R.L., Memmott, F. and Lierce, D.J. (2008). Grafting Methods for Watermelon Production. Horticultural Science. 43: 1677-1679.

Lee, J.M., Kubota, C., TsaoS, J., Bie, Z., Hoyos Echevarria, P., Morra, L. and Oda, M. (2010). Current status of vegetable grafting: Diffusion, grafting techniques, automation. Scientia Horticulturae. 127: 93-105.

Lin, Y.S., Hwang, C.H. and Soong, S.C. (1998). Resistance of bitter gourd-loofah grafts to Fusarium oxysporum f.sp. momordicae and their yield. Plant Protection Bulletin. 40: 121-132. 
Lin, Y.S. (2004). Grafting techniques for controlling fusarium wilt of bitter gourd. Fruits and Fertilizer Technology Center PT 36.

Maiko, T.K. and Musat, I.K. (1977). The effect of retardants CCC, B9 and ethrel on gibberellin activity in peaches. Introduksiya ta Aklimatiz Roskin na Ukraini Resp. 4: 90-92.

Palada, M.C. and Chang, L.C. (2003). Suggested Cultural Practices for Bitter Gourd. AVRDC pub No. 03-547. 2.

Pradeep, K., Youssef, R., Mariateresa, C. and Giuseppe, C. (2017). Vegetable grafting as a tool to improve drought resistance and water use efficiency. Frontiers in Plant Science. 8: 1130-1133.

Punithaveni, V., Jansirani, P. and Saraswathi, S. (2014). Effect of cucurbitaceous rootstocks and grafting methods on survival of cucumber grafted plants. Trends in Biosciences. 7 : 4223-4228.
Shinde, H.J., Desai, U.T., Masalkar, S.D. and Choudhari, S.M. (1994) Effect of plant growth regulators to control vine length in watermelon. Journal of Maharashtra Agricultural Universities. 19: 150-151.

Sun, Z., Lin, C.C., Gu, X.F. and Zhang, M.Y. (2009). Progress of cucurbit grafting in China. Proceedings of Fourth International symposium, AVRDC Staff Publication Region. China. 11-15.

Tamilselvi, N.A. (2013). Grafting studies in bitter gourd (Momordica charantia L.). M.Sc. (Hort) thesis, Tamil Nadu Agricultural University, Coimbatore. 213.

Yadav, R.B.R. and Sreenath, P.R. (1975). Influence of some growth regulators on growth, flowering and yield of cowpea. Indian Journal of Plant Physiology. 18: 135-139. 